\title{
Assessment of Some Biochemical Parameters for Early Detection of Protein Energy Malnutrition
}

\author{
Mohsen M. Deeb, Mostafa M. EShakankery*,Nagwa Mohamed **and \\ Ghada,ZA.Soliman*** \\ Pediatric department, Menoufiya University, Medical Biochemistry Departement, El-Minia \\ Universit $y^{*}$. Childhandicapped Center, AlAzhar University**and Biochemistry \\ Department,National NutritionInstitute ${ }^{* * * *}$
}

\begin{abstract}
Protein energy malnutrition (PEM) is a common health problem in developing countries. The mild form of PEM results in growth retardation while severe forms result in the syndromes of marasmus and kwashiorkor. Mild PEM was described as a condition in which specific or , non specific clinical signs, as well as non specific laboratory indices are present without any of the classical manifestations of nutritional deficiency.

Objective of this work was to assess serum transferrin and fibronectin as a biochemical markers for early detection of PEM. We studied 42 children: 30 patients had PEM (15 cases were mild to moderate PEM and 15 cases were severe PEM) with their age ranged between 4-36 months and the remaining 12 children were age and sex matched healthy children as controls. All studied children were subjected to: full history taking, thorough clinical examination including anthropometric measurements [weight, hight,body mass,index (BMI), and mid arm circumference (MAC)] as well as estimation of serum albumin, serum transferrin, fibronectin, $\mathrm{Hb}$ and urine analysis. Results revealed significant reduction in all anthropometric measurements in both mild to moderate and severe PEM patients as compared to control group . Serum albumin was significantly lowered in severe PEM as compared to control and still within normal level in mild to moderate PEM patients.

Serum transferrin and fibronectin were significantly lowered in mild to moderate PEM as compared to controls and more reduction in severe form of PEM as compared to controls . Serum fibronectin and transferrin correlated positively with BMI $(\mathrm{P}<0.05)$ and serum albumin ( $\mathrm{P}<0.001)$ in both mild to moderate and severe PEM . In conclusion serum fibronectin and transferrin are markedly reduced in patients with mild to moderate PEM and correlated positively with BMI and serum albumin. This represents an evidence for the role of serum fibronectin and transferrin as biochemical markers for early detection of PEM.
\end{abstract}

\section{Introduction}

PEM is a common health problem in developing countries (Tatli et al, 2000 ). The major clinical syndromes of severe PEM are marasmus, kwashiorkor (KWO) and marasmic KWO, while mild form results in growth retardation (Manary, et al., 1999, and Barltrop ,1992.). The mild form of PEM was described as a condition in which non specific clinical signs, or specific, as well as non specific laboratory indices, are present without any of the classical manifestations of nutritional deficiency ( Dahan et al., 1985.) Albumin was traditionally measured to estimate the nutritional status but it has the disadvantages of having a long half-life (18-20 days) (Behar, 1981.) So, Albumin should not be used to diagnose either recent or mild to moderate degree of PEM. Its major role is in the assessment of the severity of chronic malnutrition and in estimating prognosis, but here its clinical use is limited (Hassanein et al., 1998., Benjamin, 1989. and Veldee, 2001.) Transferrin is a major transport protein for iron and is the second most investigated protein marker in 


\section{Assessment of Some Biochemical Parameters}

malnutrition because it has a much smaller pool than albumin and shorter half-life (8-9 days) (Assem et al, 1996.). Fibronectin with short half-life (15-20 hours) falls rapidly on minimal starvation and on refeeding it is also rapidly restored often before albumin increased and before clinical improvement can be detected (Yoder et al.,1987.and Maggioni A,and Lifshitz, 1995.)

The current study was done to estimate the serum levels of transferrin and fibronectin in PEM patients and evaluate their use as biochemical markers for early detection of PEM.

\section{Subjects And Methods}

This study included 30 children (Group I) with PEM. They were 12 males and 18 females, aged from 4-36 months. They were selected from inpatient pediatric department, Minoufiya and Al Azhar Universities Hospital, 12 age and sex matched healthy children were also included as controls (Group II). The patients were classified according to Balint 1998. (Mild, moderate and severe PEM when current weight to expected weight for height is $80-90 \%, 70-80 \%$ and less of $70 \%$ respectively) into 2 subgroups:

Group IA: 15 children with mild to moderate PEM aged 4-36 months (mean 18.53 SD \pm 9.73) 8 males and 7 females.

Group IB: 15 children with severe PEM aged 4-36 months (mean 14.60 SD \pm 5.17) 4 male and 11 females.

All studied children were subjected to complete history taking and thorough clinical examination including anthropometric measurements (weight, length, MAC, BMI where BMI $\left.=\mathrm{kg} / \mathrm{m}^{2}\right)($ Hammer LD et $a l, 1991$.), and the infections in malnourished patients excluded by $\mathrm{CBC}$ for leucocytosis, urine analysis (UTI) and x-ray chest. Laboratory investigations include:

1-Serum albumin using synchron clinical system $\mathrm{CX}^{(14)}$.

2-Serum fibronectin and serum transferrin measurement :-

\section{A) Sample collection :}

A sample of $3 \mathrm{ml}$ of blood was collected and allowed to clot (30 minutes at $21^{\circ} \mathrm{C}$ ) in test tubes and were centrifuged . Serum were collected in test tubes and stored in a deep freezer .

\section{B)Measurement:-}

Quantitation of serum fibronectin and transferrin was done by Radial immunodiffusion (RID) kits (Human fibronectin RID kits \& transferrin RID kits) . It's principally derived from the work of (Manchini and Cabonra , 1965. and Fahey and McKelvey, 1965.) .

\section{Statistical Analysis:-}

Quantitative results were presented as means and standard deviations (mean $\pm \mathrm{SD}$ ) .Comparison of means was done using student t-test .Linear regression analysis with determination of correlation coefficient (r) was used for correlation between quantitative variables. $P$ value $(p)$ of $<0.05$ was taken to be statistically significant .(Mastuda et al.,1982.).

\section{Results}

The results of this study are shown in tables (1-3): Anthropometric measurements were significantly reduced in both mild to moderate and severe PEM patients as compared tocontrol group except, hight in mild to moderate PEM patients, which was still within normal range with no significant difference as compared to control $(\mathrm{P}>0.05)$ table $(1)$

The mean serum fibronectin concentration was significantly reduced $\mathrm{P}<0.05$ in severe PEM patients as compared to mild and moderate PEM patients $(82.90 \pm 35.22$ Vs $135.23 \pm 42.8 \mathrm{mg} / \mathrm{L}$ respectively) and significantly lowered $\mathrm{P}<0.001$ in both patient groups as compared to controls $(254.30 \pm 103.44 \mathrm{mg} / \mathrm{L})$.

Also, the mean serum transferrin concentration was significantly lowered $\mathrm{P}<0.001$ in severe PEM as compared to mild to moderate PEM patients $(1236 \pm 194.48$ Vs $1985.33 \pm 390.58 \mathrm{mg} / \mathrm{L})$ and significantly lowered $\mathrm{P}<0.001$ in both 
patients groups as compared to controls $(2640 \pm 413.22 \mathrm{mg} / \mathrm{L})$.

There was no significant reduction in serum albumin in mild to moderate PEM patients as compared to controls $(4.21 \pm 0.62$ Vs $4.61 \pm 0.62 \mathrm{gm} / \mathrm{dl}) \quad$ it stowed, but a significant decrease $\mathrm{p}<0.001$ in serum albumin level in severe PEM patients as compared to mild to moderate
PEM patients $(2.83 \pm 0.76$ Vs $4.21 \pm 0.62$ $\mathrm{gm} / \mathrm{dl}$ ) and also, when compared to control $(2.83 \pm 0.76$ Vs $4.61 \pm 0.62 \mathrm{gm} / \mathrm{dl}) \mathrm{p}<$ 0.001 table (2). Serum transferrin level showed significant positive correlation with BMI, serum albumins and fibronection. Also, there was significant positive correlation between serum fibronectin and each BMI and serum albumin table (3).

Table (1): Comparison of Anthropometric measurements between studied groups:

\begin{tabular}{|c|c|c|c|c|c|c|}
\hline & $\begin{array}{l}\text { Controls } \\
\text { G11 } \quad n=12 \\
\overline{\mathrm{X}} \pm \mathrm{SD}\end{array}$ & $\begin{array}{l}\text { Mild-moderate } \\
P E M \\
\text { GIA } \quad n=15 \\
- \\
\mathrm{X} \pm \mathrm{SD}\end{array}$ & $\begin{array}{l}\text { Severe PEM } \\
\text { GIB } \quad n=15 \\
\overline{\mathrm{X}} \pm \mathrm{SD}\end{array}$ & $P 1$ & $P 2$ & $P 3$ \\
\hline Age (mo) & $18.20 \pm 8.80$ & $18.53 \pm 9.73$ & $14.60 \pm 5.17$ & $>0.05$ & $>0.05$ & $<0.05$ \\
\hline Weight (kg) & $11.65 \pm 2.17$ & $7.46 \pm 1.71$ & $5.27 \pm 1.76$ & $<0.001$ & $<0.001$ & $<0.001$ \\
\hline Hight $(\mathrm{cm})$ & $82.90 \pm 9.64$ & $79.70 \pm 10.15$ & $66.90 \pm 6.56$ & $<0.001$ & 0.05 & $<0.001$ \\
\hline BMI & $15.2 \pm 1.5$ & $13.6 \pm 1.2$ & $9.2 \pm 3.2$ & $<0.05$ & $<0.05$ & $<0.0 \mathrm{o} 1$ \\
\hline MAC $(\mathrm{cm})$ & $14.05 \pm 1.34$ & $11.96 \pm 1.34$ & $9.56 \pm 2.51$ & $<0.001$ & $<0.05$ & $<0.001$ \\
\hline \multicolumn{7}{|c|}{$\begin{array}{ll}\text { P1 } & \text { Group1AVs Group1B } \\
\text { P2 } & \text { Group IA Vs Group11 }\end{array}$} \\
\hline
\end{tabular}

Table (2): Comparison of some biochemical parameters between studied groups:

\begin{tabular}{|c|c|c|c|c|c|c|}
\hline & $\begin{array}{l}\text { Controls } \\
\text { G11 } \quad n=12 \\
\overline{\mathrm{X}} \pm \mathrm{SD}\end{array}$ & $\begin{array}{l}\text { Mild-moderate } \\
P E M \\
\text { GIA } \quad n=15 \\
\overline{\mathrm{X}} \pm \mathrm{SD}\end{array}$ & $\begin{array}{l}\text { Severe PEM } \\
\text { GIB } \quad n=15 \\
\overline{\mathrm{X}} \pm \mathrm{SD}\end{array}$ & $P 1$ & $P 2$ & $P 3$ \\
\hline $\begin{array}{l}\text { S. Fibronectin } \\
(\mathrm{mg} / \mathrm{L})\end{array}$ & $254.30 \pm 103.44$ & $135.23 \pm 42.81$ & $82.90 \pm 35.22$ & $<0.05$ & $<0.001$ & $<0.001$ \\
\hline $\begin{array}{l}\text { S. Transferrin } \\
(\mathrm{mg} / \mathrm{L})\end{array}$ & $2640.0 \pm 413.22$ & $\begin{array}{l}1985.33 \pm 390.5 \\
8\end{array}$ & $\begin{array}{l}1236.00 \pm 194 . \\
48\end{array}$ & $<0.001$ & $<0.001$ & $<0.001$ \\
\hline $\begin{array}{l}\text { S. Albumin } \\
(\mathrm{gm} / \mathrm{dL})\end{array}$ & $4.61 \pm 0.62$ & $4.21 \pm 0.62$ & $2.83 \pm 0.76$ & $<0.001$ & $>0.05$ & $<0.001$ \\
\hline
\end{tabular}




\section{Assessment of Some Biochemical Parameters}

Table (3) Correlation between transferrin and Fibronectin and some studied parameters in malnourished groups:

\begin{tabular}{|c|c|c|c|c|}
\hline & \multirow{2}{*}{\multicolumn{2}{|c|}{$\begin{array}{l}\text { Mild-moderate } P E M \\
\text { GIA } \quad n=15\end{array}$}} & \multicolumn{2}{|c|}{ Severe PEM } \\
\hline & & & $G I B$ & $n=15$ \\
\hline & $\mathrm{r}$ & $\mathrm{P}$ & $\mathrm{r}$ & $\mathrm{P}$ \\
\hline TRS/BMI & 0.622 & $<0.05$ & 0.540 & $<0.05$ \\
\hline TRS/Alb & 0.82 & $<0.001$ & 0.807 & $<0.001$ \\
\hline TRS/bibr & 0.929 & $<0.001$ & 0.773 & $<0.001$ \\
\hline Fibr/BMI & 0.456 & $<0.05$ & 0.591 & $<0.001$ \\
\hline Fibr/Alb & 0.939 & $<0.001$ & 0.819 & $<0.001$ \\
\hline
\end{tabular}

TRS $=$ Transferrin

Fibr $=$ fibronectin

$* \mathrm{P}>0.05=$ significant

$$
\begin{gathered}
\text { Alb }=\text { Albumin } \\
\text { BMI }=\text { Body mass index } \quad * \mathrm{P}<0.05=\text { significant }
\end{gathered}
$$

\section{Discussion}

PEM still represents one of the most common health problems in the pediatric age group in Egypt (Ramadan et al.,1994). In the present study all anthro-pometric measurements were significantly reduced in mild to moderate and severe malnourished patients compared to controls, except hight which was not affected in mild to moderate PEM children. These results expected to be due to muscle wasting, loss of subcutaneous fat and growth failure in malnourished children. These results were parallel to those obtained by ( Abd el-Ghany et al., 2003., Choudhary ,2001., Fayed et al , 2002. and Fumodu et al.,2002) found significant reduction in body weight, MAC and Triceps - SFT in group of malnourished african children. Our results showed significantly reduction $\mathrm{P}<0.001$ of mean level of serum albumin in severe PEM as compared to control group. However, in our mild to moderate PEM group, serum albumin values were actually still within normal range with no significant difference as compared to control group. These results indicated that albumin is not a sensitive indicator of mild to moderate PEM, as it was a good marker in severe PEM and had the disadvantage of having a long half-life (18-20 days) (Hassanein et al., 1998). In the current study, the mean serum level of fibronectin was significantly reduced in both mild to moderate and severe PEM groups. So the more the degree of malnutrition, the more the decrease in the level of fibronectin. These results was observed by others who reported that fibronectin levels were lower in mild to moderate PEM. (Abdel-Ghany et al.2003.). So, fibronectin may provide a biochemical functional index of mild to moderate PEM. Reduction of serum fibronectin in malnourished patients could be attributed to decrease synthesis, increase degradation or tissue redistribution of soluble fibronectin to insoluble form (Akenami ,1997.).

In the present study, there was significantly reduction in serum transferrin levels in patients with mild to moderate and severe PEM. These results indicated that transferrin is a sensitive nutritional marker for mild to moderate degree of PEM. This finding was in accordance to those obtained by (Johnson ,1999 and Hassanein et al., 1998). Reduced transferrin levels in children with malnutrition may due to reduction of its synthesis in the liver (Akenami et al.,1997.).

In the present study, the serum level of tranferrin was positively correlated with 
BMI, serum albumin and fibronectin in both mild to moderate and severe PEM groups. Also serum level of fibronectin was positively correlated with BMI and serum albumin in both mild to moderated and severe PEM group, many studies have demonstrated the same positive correlation .(Akenami et al.,1997)

\section{Conlusion}

Serum transferrin and fibronectin are markedly reduced in mild to moderate malnourished children and correlated positively with BMI and albumin. This represents an evidence for the role of serum fibronectin and transferrin as biochemical markers for early detection of PEM.

\section{References}

1. Abdel-Ghany SM, Hgag WW, Khalil IM, El-Mahdy MIM, and El-Sayed M, (2003): Serum Leptin Levels in children with severe protein energy malnutrition: correlation with insulin, cortisol and thyroid hormones; The Gaz. Egypt. Paed., 51(3,4): $173-83$

2. Akenami FO, Koskiniemi M, Siimes MA, Ekanem EE, Bolarin DM and Vaheri A, (1997): Assessment of plasma fibronectin in malnourished Nigerian children. $\mathrm{J}$ Pediatr Gastroenterol Nutr;,4(2):183-8

3. Assem H, Abdel-Fattah $M$ and Mahdy Nand Sharaky O,(1999): Plasma fibronectin, serum apoproteins, albumin and transferrin concentration during nutritional repletion in PEM. Egypt $\mathbf{J}$ Pediatric; 13:209-24.

4. Balint JP ,(1998) : "Physical findings in nutritional deficiencies" Pediatr. Clin North Am; 45:245-260.

5. Barltrop B ,(1999): Nutrition. In: Campbell AGM, McIntosh N, eds. Forfar and Arneils. Textbook of Pediatrics, $4^{\text {th }}$ eds., Vol. 3, Edinburgh: Churchill Livingstone . 1257-1298.

6. Behar M, (1981) : What is marginal malnutrition? Nutrition in Health and Disease and International Development. Harper AE and Davis GK, New York. 237-47.
7. Benjamin DR,(1998): Laboratory tests and nutritional assessment in PEM. Pediatrics Clin North Am; 936 (1): 139-61.

8. Choudhary RP, (2001) : "Anthropometric indices and Nutritional deficiency signs in preschool Children of the pahariya trib of the Rajmahal Hills, Bihar", Anthoropol. Anz., 59:61-71

9. Dahan MS, Jacobs $\mathbf{L}$ and Smith $\mathbf{S}$ (1997): The significance of hypoalbuminemia following injury and infection. Am Surg; 51:340 -49

10. Doumas BT, and Briggs HG , (1982) : Determination of serum albumin, standard methods. Clin. Chemistry;,7:175 - 83

11. Fahey JL and McKelvey EM ,(1965): Quantitative determination of serum immunoglobulins in antibody-agar plates. J. Immunol; 94:84-90

12. Fayed SB, Abdel-Ghany SM, Aref MI and Swidan DME ,(2002): Serum Soluble ICAM-I levels in infants with protein energy malnutrition". Z.U.M.J; Vol VIII, No 5, Sep: 1151-63.

13. Fumodu AA, Adebaweo OO, Fakoya EA, OKosum QA , (2002): "Serial haematological changes in malnourished Afiricum children" west Afr. J, Med; 21:91-94.

14. Hammer LD, Kraemer HC, Wilson DM:,(1991): standerdized percentile cerves of Body mass index for childrenand adolescents. Am. J. Dis. Child, 145:259 -67

15. Hassanein EA, Assem HM and Rizk MM, (1998) : Study of plasma albumin, transferrin and fibronectin in children with mild to moderate PEM. Journal of Tropical Pediatrics; December;44(6): 362-5.

16. Johnson AM, (1999): Low levels of plasma proteins: malnutrition or inflammation? Clin Chem Lab Med, Feb; 37(2): 91-6.

17. Maggioni A and Lifshitz F, (1995): Nutritional management of failure to thrive. Pediatric Clin North Am; 42 (4): 791-806.

18. Manary $M$, Broad head $R$ and Yarasheski KE, (1999) :"Whole-body protein Kinetics in marasmus and Kwashiorkor during acute infection" Am. J. Clin Nutr; 67:1205-1209.

19. Manchini G and CabonaraAO,(1982) : Immunochemical quantitation of antigen by single radial immunodiffusion. Immunochem; , 2:235-254.

20. Matsuda M ,Yamada T, and Matsuda A, (1982) :Distribution of fibronectin in 


\section{Assessment of Some Biochemical Parameters}

plasma and liver in liver diseases.Chem Acta; 118:191-199.

21. Ramadan MA, El-Sherbiny AF, Eissa AM, El-Shafie A and El-Gazzar F (1994): Protein energy malnutrition and its relation to food habits in Menoufiya. M.D. Thesis, Menoufiya University.

22. Reeds PJ,and Laditan AA (1976) : serum albumin and transferrin in protein energy malnutrition. Their use in the assessment of marginal undernutrition and the prognosis of severe undernutrition . $\mathrm{Br} \mathbf{J}$ Nutr ; Sep ;36(2):255-63.

23. Rockettc HE, (1999): "Occupational biostatistics. In: Environmental occupational medicine. Romwn (Ed). $3^{\text {rd }}$ Ed, Pheladelphia, New York, Lippincott, Raven Ch. 8, P 57-66.
24. Tatli MM, Vural $H$ and Koc $A$ : (2000)"Altered anti-oxidant status, and increased lipid perioxidation in marasmic children". Pediatr Int; 8: 289-92.

25. Veldee MS, (2001): Nutritional assessment therapy and monitoring. In: Tietz fundamental of clinical Chemistry. Burtis CA and Ashwood ER (eds), $5^{\text {th }}$ edition, WB Saunders Company, pp. 950-954.

26. Yoder MC, Andersen DC, Cropalakrishna GS, Douglas SD and Polin RA , (1987):, Comparison of serum fibronectin, Prealbumin and albumin concentration during nutritional reflection in protein calorie malnurished infants. J Pediatr Gastroenterol Nutr, Jan-Feb; 6(1): 84-88. 


\title{
تقييم بعض الإختبارات الحيوية لإستكشاف نقص البروتين في حالات سوء التغذية
}

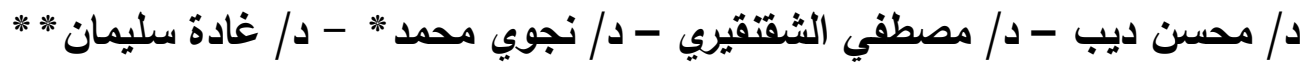

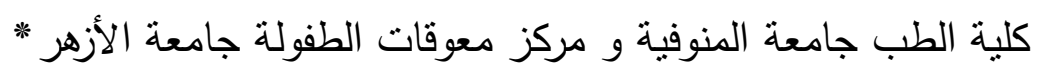 \\ ومعهد التغّذية القومى * معرد
}

إن نقص البروتين من المشاكل الثـائعة في البلاد النامية و يسبب حدوثه تأخر في النمو في

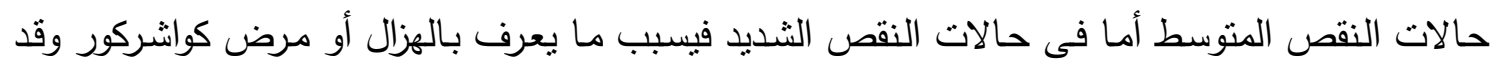

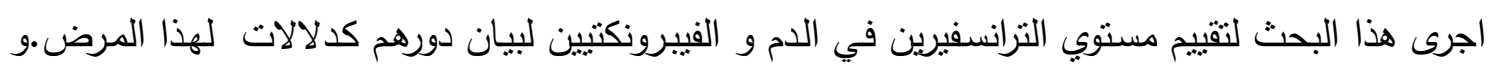
بدراسة عدد 42 طفل منهم 30 مريض (15 نقص متوسط ، 30 نقص شديد) في سن من 6 - 36 شهرا

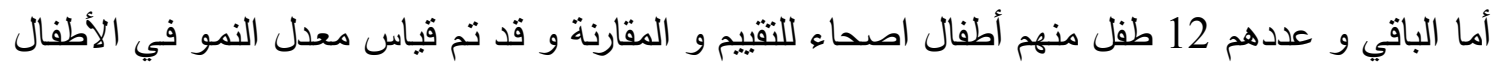

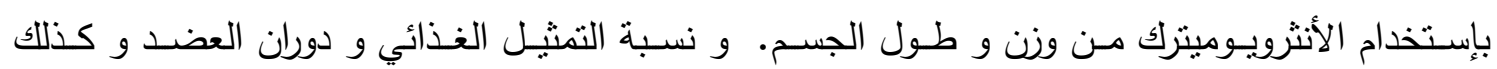
مستوي الألبومين و الترانسفيرين و الفييرونكتين و الهيموجلوبين في للام.

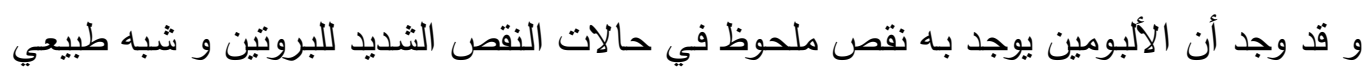

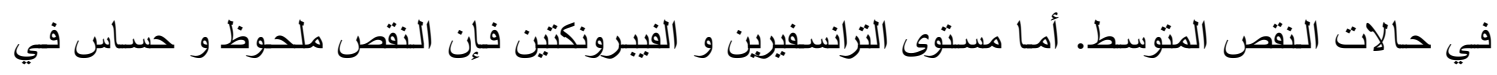

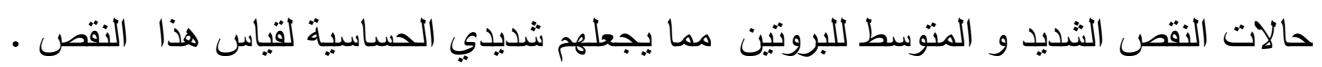

